\title{
Assessment of Antimicrobial Activity and Healing Potential of Mucous Secretion of Achatina fulica
}

\author{
Evaluación de la Actividad Antimicrobiana y la Cicatrización \\ Potencial de la Secreción Mucosa de Achatina fulica \\ *,**Wagno Alcântara Santana; *,***Cláudia Moura de Melo; *,**Juliana Cordeiro Cardoso; ",** Rose Nely Pereira-Filho; \\ "Alessandra Silva Rabelo; "Francisco Prado Reis \& ",*** Ricardo Luiz Cavalcanti de Albuquerque-Júnior
}

SANTANA, W. A.; MElo, C. M.; CARDOSO, J. C.; PEREIRA-FILHO, R. N.; RABELO, A. S.; REIS, F. P. \& ALBUQUERQUEJÚNIOR, R. L. C. Assessment of antimicrobial activity and healing potential of mucous secretion of Achatina fulica. Int. J. Morphol., 30(2):365-373, 2012.

SUMMARY: Achatina fulica's secretion has been recently related to antibacterial, antifungal, and cicatricial properties, and it is influenced by the kind of food offered. Therefore, this study investigated the healing potential of dressing films based on mucous secretion of Achatina fulica. Thus, surgical wounds performed in black wistar rats were dressed with films based on collagen, and on mucous secretion of A. fulica fed with Lactuca sativa; undresses worked as wounds control. After 3, 7, 14 and 21 days the animals were euthanized, and the wounds were microscopically evaluated. On the 3rd and 7th days dressing films based on mucus provided acceleration of the formation maturation of granulation tissue, better epithelization rates, and more rapid replacement of type III for type I collagen fibers. On the 14th and 21st days, these dressings induced more intense deposition and better architectural disposition of type I collagen fibers, and hastened the regeneration of cutaneous phaneros. Dressings obtained from A. fulica fed with Lactuca sativa provided the most expressive results. This study suggests that films produced with mucous secretion of $A$. fulica can be successfully employed as wound dressing, particularly if snails are fed with Lactuca sativa.

KEY WORDS: Wound healing; Wound dressing; Land snails; Mucus.

\section{INTRODUCCIÓN}

Second-intention dermal wound healing is a highly complex physiopathological phenomenon of skin repair that involves substantial loss of substance and consequent delay on the scar formation (Martin, 1997; Singer \& Clark, 1999). The analysis of the kinetic of this biological process in response to different forms of dermal substitution is important for the development of efficient therapeutic products capable of stimulating the wound healing (Werner \& Grose, 2003; Diegelman \& Evans, 2004).

In recent years, there have been many recent advances in wound healing and dermal substitution research, but no product described in experimental studies is so far able to fully substitute the natural living skin (Shakespeare, 2001). It has been demonstrated that the application of occlusive dressings prevents bacterial growth and wound infection and therefore improves wound healing. The decreased infection rates might be a result of the large number of activated neutrophils in the wound fluid, prevention of exogenous bacterial contamination, and prevention of tissue dessication and necrosis (Ojiegbe et al., 1990). In this vein, the use of natural polymers has been employed as occlusive dressings in healing of dermal wounds owing to their biocompatibility, nontoxic properties, and ease and safety of the application on dermis (Albuquerque-Júnior et al., 2009; Nunes et al., 2011).

Achatina fulica is a land snail able to produce a glycoproteic secretion which has been demonstrated to present some biological effects, such as antibacterial properties against gram positive and negative microorganisms (Iguchi et al., 1982; Kubota, 1985; Martins et al., 2003; Sirio et al., 2005, Lorenzi \& Martins, 2006). Furthermore, mucus of this snail has been tested in surgical wounds of experimental animals and proved to improve the dermal cicatricial repair (Martins et al.; Sirio et al.).

\footnotetext{
* Science and Technology Institute, Aracaju/SE, Brazil.

** Post-Graduation program in Health and Environment, University Tiradentes, Aracaju/SE, Brazil.
} 
Therefore, the goal of this study is to assess the antimicrobial activity and healing potential of $\mathrm{n}$ mucous secretion of Achatina fulica, processed as occlusive dressing films, upon dermal cicatricial repair in rodents.

\section{MATERIAL AND METHOD}

Snail Samples. Thirty non-infected land snails Achatina fulica proceeded from the Snail Research Station (SRS) of the Science and Technology Institute (STI/Aracaju/SE, Brazil), weighing $45 \pm 5 \mathrm{~g}$, were selected for this study. The animals were housed in wood timber boxes $(35 \mathrm{~cm}$ width $\mathrm{x}$ $30 \mathrm{~cm}$ height), with land bedding added to calcium carbonate (to provide calcium levels required for shell development), containing 30 snails each. The boxes were sprinkled daily with water in order to maintain the humidity. The animals were randomly assigned into experimental groups $(n=30)$, was fed with a of plant (Lactuca sativa).

Obtaining of mucous secretion. In order to avoid contamination of the biological material to be collected, the snails were housed individually in plastic cages $(75$ x 40 $\mathrm{x} 30 \mathrm{~cm}$ ) and kept under abstinence from food for 3 days. Subsequently, approximately $5 \mathrm{~mL}$ of mucous secretion was collected by manual stimulation of the podal glands of the snails. Euthanasia of the snails was not necessary to obtain the mucus, so that the animals were re-delivered to the SRS/ STI thereafter.

Antimicrobial activity. Strains of Candida albicans ATCC 10231, Escherichia coli ATCC 15878, Pseudomonas aeruginosa ATCC 1024, Staphylococcus aureus ATCC 9080, Staphylococcus epidermides ATCC 19606, Fusarium ATCC 9605, ATCC 5487 Salmonella from the BIOSLAB (Rio de Janeiro) was used for microbiological testing. The antimicrobial activity was performed by diffusion wells according to the method described by Shriyan et al. (1995). $\mathrm{BHI}$ broth was inoculated with the microorganisms and incubated at $37^{\circ} \mathrm{C} / 24$ horas. After this period, the inoculum was adjusted to McFarland scale tube 0.5 (1.5 x $108 \mathrm{CFU})$ in saline. Was inoculated by spreading on plates containing Mueller-Hinton Agar $\mathrm{m}$ and Sabouraud agar inocula adjusted to the McFarland scale. We used $5 \mathrm{~mL}, 10 \mathrm{~mL}$ and $20 \mathrm{~mL}$ respectively, of mucus containing the feeds, which were deposited into wells and incubated for 24 hours at $37^{\circ} \mathrm{C}$. The inhibitory activity was determined by measuring the zone of inhibition.

To determine the minimal fungicidal concentration were used tubes containing $5.0 \mathrm{~mL}$ of BHI broth, $4 \mathrm{~mL}$ of mucus in each group, followed by serial dilution concentrations producing between 290 and 14,800 mg.mL1 of mucus (Martins et al., 2003). To the tubes we added 1 $\mathrm{mL}$ of each inoculum of $0.5 \mathrm{McFarland}$ (1.5 x $108 \mathrm{CFU}$ ) and incubated for $37^{\circ} \mathrm{C} / 24$ hours (Cruse \& Foord, 1980; Moylan \& Kennedy, 1980). After this period, $100 \mathrm{~mL}$ of the contents of the tubes were inoculated on the surface in Sabouraud agar plates, which were incubated at $37^{\circ} \mathrm{C} / 24$ hours. This experiment was performed in triplicate. After the incubation period plates were observed that showed fungal growth. As positive controls we used metronidazole and miconazole commercial at the same concentrations of mucus tested.

Preparation of the films. The film dispersion was prepared using $20 \mathrm{~mL}$ of mucus (3.975g) and polyethylene glycol 400 (PEG400), which was employed as plasticizer. The proportion of plasticizer used was $2 \% \mathrm{w} / \mathrm{w}$ of dry mucus. This dispersion was homogeneizated and the films were obtained by casting process. The films obtained in this step of the experiment were cut off in square shape $(2 \times 2 \mathrm{~cm})$ and sterilized in UV rays.

Surgical Procedures and Group Formation..The animals used for the biological assay were 100 adult male Rattus norvegicus albinus, Wistar lineage, weighing $250-300 \mathrm{~g}$. The rats were housed in clear plastic cages with solid floors and loose hardwood chip bedding, and supplied with food and water ad libitum in a temperature and humidity-controlled environment. The animals were anesthetized with intraperitoneal ketamine-xylazine $(100 \mathrm{mg} / \mathrm{kg}-5 \mathrm{mg} / \mathrm{kg})$ and $1 \mathrm{~cm} 2$ standard-sized square-shaped wounds were performed in the back of the animals. Animals were handled in accordance with the principles of aseptic chain in order to avoid any possibility of exogen bacterial contamination. Subsequently, rats were randomly assigned into three groups of twenty animals each, $\mathrm{CG}$ - undressed control group; $\mathrm{CoG}$ - dressed with collagen-based films and ACF group dressed with films obtained from mucus of A. fulica fed with Lactuca sativa.

Histological procedures. After death certification, the area corresponding to the wound region in the back of the animals was surgically removed and the specimens were formalinfixed and paraffin-embedded according to routine laboratorial techniques. Subsequently, serial $5 \mu \mathrm{m}$ thick sections were obtained and stained in hematoxylin-eosin to perform the analysis of the inflammatory reaction, and picrosírius, analyzed under polarized light, to study the deposition of collagen fibers, and toluidin blue, to assess the mast cells population.

Assessment of the inflammatory profile (IP). The intensity of the inflammatory response was assessed in histological 
sections as follows: - (lack of inflammatory reaction); + (inflammatory cells representing less than $10 \%$ of the cell population observed within the wound area); ++ (inflammatory cells representing between 10 and $50 \%$ of the cell population observed within the wound area); and +++ (inflammatory cells representing more than $50 \%$ of the cell population observed within the wound area). Moreover, the profile inflammatory (IP) was classified as acute (predominance of polymorphonuclear cells) and chronic (predominance of mononuclear cells), and graded as slight, absent, moderate or severe.

Assessement of the percentage of collagen deposition (COD). Histological sections stained in picrosirius and analyzed under polarized light were used to the descriptive analysis of the collagen deposition. Collagen fibers were analyzed according to their birefringence pattern (greenish/ yellow-greenish or orange, orange-reddish), morphological appearance (wavy or stretched, thin or thick, short or long) and disposition (reticularly arranged or interlaced). The quantitative analysis of the area occupied by collagen fibers in the healing area was determined by optical density in the image analysis system in different randomly selected fields. The system used consists of a CCD Sony DXC-101 camera, applied to a Olympus CX31 microscope, from which the images were sent to a monitor (Trinitron Sony). By means of a digitizing system (Olympus C-7070 WIDEZOOM) the images were inserted into a computer (Pentium $133 \mathrm{MHz}$ ), and processed by a software (ImageTool). A total of ten fields per case were analyzed at a magnification of 100x. The thresholds for collagen fibers were established for each slide, after enhancing the contrast up to a point at which the fibers were easily identified as birrefringent (collagen) bands. The area occupied by the fibers was determined by digital densitometric recognition, by adjusting the threshold level of measurement up to the different color densities of the collagen fibers. The area occupied by the fibers was divided by the total area of the field. The results were expressed in percentage of the skin area fraction occupied by the collagen fibers.

Statistical analysis. Statistical significant difference in the

Table I- Antimicrobial activity of mucus of Achatina fulica.

\begin{tabular}{lcc}
\hline \multirow{2}{*}{ Mucus $(\mu \mathrm{L})$} & \multicolumn{2}{c}{ Inibition zone $(\mathbf{m m})$} \\
\cline { 2 - 3 } & Staphylococus aureus & Staphylococus epidermidis \\
\hline $\mathbf{5}$ & 0.00 & 0.00 \\
$\mathbf{1 0}$ & 9.30 & 10.29 \\
$\mathbf{2 0}$ & 13.15 & 15.20 \\
Statistics & $p=0.0000652$ & $p=0.0000000005$ \\
\hline
\end{tabular}

severity of the IP was assessed by chi-squared test, whereas the significances of the differences in the COD rates were verified by analysis of variance (one-way ANOVA) and Tukey test. Each time point was analyzed separately, and two-tailed a-level of $\mathrm{p}=0.05$ was significant.

Ethics Considerations. Prior the beginning of any experimental procedure, this study was approved by our Animal Care and Use Committee (register 101107).

\section{RESULTS AND DISCUSION}

Antibacterial activity. In Table I, the results of the antimicrobial tests were presented. Inhibition zone (Iz) was observed against Staphylococus aureus and Staphylococus epidermidis, and the higher was the concentration of the mucus the larger was the diameter of the inhibition halos $(\mathrm{p}<0.05)$. No significant difference was observed in the inhibitory activity of the mucus regarding both microorganisms $(p>0.05)$ nor between them and metronidazole $(\mathrm{p}>0.05)$.

Morphological analysis of the histological sections stained in HE. The semiquantitative analysis of IP rates is presented Table II. It was observed that the severity of the inflammatory response descreased in the groups in time, but no significant difference was observed among the groups in any of the experimental periods ( $p>0.05)$. However, the pattern of the leukocyte infiltrate varied in the experimental groups in time, as follows:

3rd day. In CTR and COL there was intense infiltration of neutrophils, particularly in the surface of the specimens, and prominent interstitial edema. Despite foci of tissue lysis could be seen, they were considered inconspicuous. Moreover, in the bottom of the wounds, intense lymphocytic infiltrate was observed in association to dense proliferation of spindleshaped cells consistent with angioblasts, sometimes forming few small thin capillary vessels. In ACF, extensive hemorrhagic areas and rich network of capillary vessels formation were verified (Fig. $1 \mathrm{a} / \mathrm{b} / \mathrm{c}$ ).

7th day. CTR showed maintenance of acute neutrophils-rich infiltrate in the top of the wounds, and copious granulation tissue, in a predominantly angioblastic phase, in the bottom. COL presented exuberant granulation tissue, and deposition of wavy thin delicate bundles of eosinophilic fibrils consistent with collagen. Adipocytic infiltration was occasionally observed. Epithelization was still inconspicuous 
in both groups. In ACF the granulation tissue was exuberant, but presented in a fibrovascular phase, with prominent fibroblastic proliferation.

14th day. In all groups, there was residual moderate inflammatory infiltrate, rich in lymphocytes, associated with scanty congested blood vessels. In addition, eosinophilic parallel-arranged fibrous bundles, with wavy appearance and varied thickness, could be observed. In COL and $\mathrm{ACF}$, however, the collagen fibers were more apparent, and composed of thicker parallel-arranged fibers.

21st day. No residual inflammatory infiltrate was observed in any control or experimental group. The fibrous
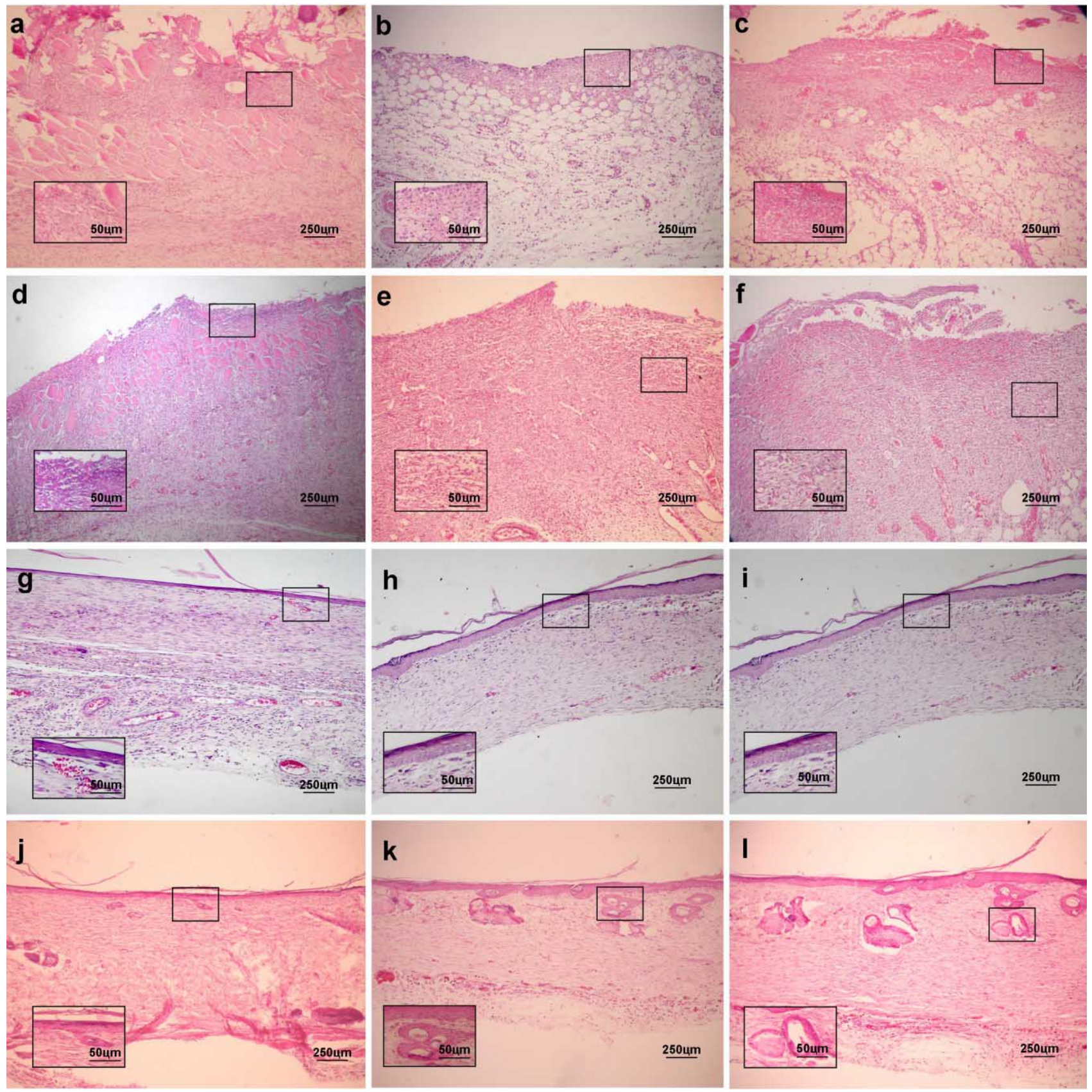

Fig. 1. Histological sections stained in HE. Presence of inflammatory infiltrate rich in polymorphonuclear neutrophils in CTR(a), COL (b) and ACF (d). Intense subacute inflammatory response in CTR (d), and granulation tissue well-developed seen in COL (e) and ACF (f) after 7 days. Residual granulation tissue seen in CTR (g) whereas collagen scar formation was observed in Col (h) and ACF (i) after 14 days. Advanced epithelization is also evidenced in all groups. In 21 days, there was lack of inflammatory response in all groups but the neoformation of cutaneous appendages was rudimentary in CTR (g) but quite advanced in COL (h) and ACF (i). 
connective tissue was dense and moderately cellular, although the collagen fibers tended to be parallel-arranged in CTR but interlaced in COL and ACF. However, neoformation of cutaneous appendages were more advanced in COL and ACF.

Table II. Assessment of the intensity of the inflammatory infiltrate in CTR (control group), COL (collagen-based group) and ACF (Achatina fulica group) during the time course of the experiment. $(-)=$ lack of inflammatory reaction; $(+)=$ mild inflammatory infiltrate, representing less than $10 \% ;(++)=$ moderate inflammatory infiltrate, representing between 10 and $50 \% ;(+++)=$ intense inflammatory infiltrate, representing more than $50 \%$.

\begin{tabular}{|c|c|c|c|c|}
\hline \multirow[b]{2}{*}{ Days } & \multirow{2}{*}{ Animals } & \multicolumn{3}{|c|}{ Inflammatory Reaction Intensity } \\
\hline & & CTR & COL & ACF \\
\hline \multirow{5}{*}{3} & $\mathrm{R} 1$ & +++ & ++ & +++ \\
\hline & $\mathrm{R} 2$ & +++ & +++ & +++ \\
\hline & R3 & +++ & ++ & +++ \\
\hline & $\mathrm{R} 4$ & +++ & +++ & +++ \\
\hline & R5 & ++ & +++ & ++ \\
\hline \multirow{5}{*}{7} & $\mathrm{R} 1$ & +++ & ++ & ++ \\
\hline & $\mathrm{R} 2$ & +++ & ++ & ++ \\
\hline & $\mathrm{R} 3$ & +++ & ++ & ++ \\
\hline & $\mathrm{R} 4$ & +++ & + & + \\
\hline & R5 & +++ & + & + \\
\hline \multirow{5}{*}{14} & $\mathrm{R} 1$ & + & + & + \\
\hline & $\mathrm{R} 2$ & ++ & + & + \\
\hline & $\mathrm{R} 3$ & + & + & + \\
\hline & $\mathrm{R} 4$ & + & + & + \\
\hline & R5 & ++ & + & + \\
\hline \multirow{5}{*}{21} & $\mathrm{R} 1$ & - & - & - \\
\hline & $\mathrm{R} 2$ & - & - & - \\
\hline & R3 & - & - & - \\
\hline & $\mathrm{R} 4$ & - & - & - \\
\hline & R5 & - & - & - \\
\hline
\end{tabular}

Table III. Assessment of the percentage of collagen deposition (COD) in the tested groups during the time course of the experiment. Different letters in the same line represent significantly different values $(\mathrm{p}<0.05)$.

\begin{tabular}{lccc}
\hline \multirow{2}{*}{ Days } & \multicolumn{3}{c}{ Percentage of Collagen Deposition (\%) } \\
\cline { 2 - 4 } & CTR & COL & ACF \\
\hline $\mathbf{3}$ & $5.25 \pm 0.14^{\mathrm{a}}$ & $7.02 \pm 0.008 \mathrm{~b}$ & $10.00 \pm 0.13 \mathrm{c}$ \\
$\mathbf{7}$ & $15.61 \pm 0.12 \mathrm{a}$ & $18.01 \pm 0.07 \mathrm{~b}$ & $25.06 \pm 0.19 \mathrm{c}$ \\
$\mathbf{1 4}$ & $29.14 \pm 0.18 \mathrm{a}$ & $35.28 \pm 0.09 \mathrm{~b}$ & $38.99 \pm 0.12 \mathrm{c}$ \\
$\mathbf{2 1}$ & $37.14 \pm 0.22 \mathrm{a}$ & $44.76 \pm 0.11 \mathrm{~b}$ & $49.05 \pm 0.14 \mathrm{c}$ \\
\hline
\end{tabular}

\section{Morphological analysis of the histological sections stained in Sirius red (observed under polarized light)}

3rd day. Scanty delicate birefringent greenish and yellowgreenish reticularly-arranged collagen fibrils, with abundant interfibrilar spaces, were observed in all three groups.

7th day. Greenish and yellow-greenish collagen fibrils were scanty and quite delicate in CTR, particularly in the surface of the wounds. In COL, the fibrils were more conspicuous and the reticular arrangement was more apparent, whereas in ACF there was deposition of some few delicate orange fibers in addition to the yellow-greenish ones, whose arrangement tended to be parallel to the surface of the wounds.

14th day. CTR presented short thin collagen fibrils with both yellow-greenish and orange birefringence, and interfibrillar spaces were quite apparent. In COL, the fibers were longer, but delicate, and there was a significant amount of orange fibers, although greenish ones were abundant. In $\mathrm{ACF}$, orange fibers were predominant, and they were thicker than in the last two groups but less compactly disposed in the surface of the wounds than in the bottom.

21st day. CTR showed thick gross and orange collagen fibers in parallel arrangement. COL and ACF presented gross orange and reddish fibers, but they tended to assume a characteristic interlaced disposition.

In Table III, the results of the morphometrical analysis of the collagen deposition was presented. Both dressed groups showed significantly higher contents of collagen fibers than CTR in all the experimental periods $(\mathrm{p}<0.00)$. Moreover ACF exhibited the more expressive rates of COD than COL in $7(\mathrm{p}=0.001)$ and 14 days $(\mathrm{p}=0.01)$.

In this study, the mucous secretion of A. fulica inhibited the bacterial growth of both Staphylococcus aureus and Staphylococus epidermidis. Other studies attesting the antibacterial properties of the mucus of invertebrate snails have been previously reported (Iguchi et al.; Kubota; Martins et al.; Sirio et al.; Lorenzi \& Martins, 2006). It has been proposed that this mucous secretion is rich in lysozyme, opsonines, and other antibacterial and antiviral factors (Fuchino \& Barrett, 1992). In addition, mucus of Achatina fulica was proved to be rich in Achactin, a high molecular weight glycoprotein belonging to the family of aminoxydase capable of lysing the cytoplasm membrane of bacteria in active proliferative phase, but not in quiescent ones, a toxical effect similar to that produced by penicillin 
(Ehart \& Floyd, 2002). Notwithstanding, these mechanisms may be related to the antimicrobial activity of the mucous secretion, further research is needed in order to fully clarify this issue.

Staphylococcus aureus is the most common cause of posttraumatic skin and soft tissue infections (Onche \& Adedeji, 2004) and this microorganism has been reported as the commonest isolate from post-operative wound injection (Rich \& Whittaker, 2005). Staphylococus epidermidis, on the other hand, has been related to high antibacterial resistance rates and nosocomial infections (Antunes et al., 2008). Therefore, since the healing is known to be affected by tissue bacteria concentrations higher than $10^{5}$ microorganisms per gram (Chong et al., 2002), the use of dressing materials able to reduce content of these microorganisms in surgical dermal wounds, as performed in this study, might be useful to avoid wound infection and, therefore, favor wound healing (Ojiegbe et al.).

Previous investigations attesting the healing potential of the mucus of Achatina fulica have been reported in this decade (Caetano, 2000; Yomassa, 2002; Martins et al.; Sirio et al.), but this is the first one to process this biological material as films for wound dressing. In this study, neither infiltration of eosinophils, a typical morphological sign of allergenic reaction (Chowdary et al., 2003), nor clusters of epithelioid and foreign body giant cells, classical feature of biological incompatibility (Maluf-Meiken et al., 2006) were observed within the wounds, attesting the good acceptability of the films by dermal tissues of the animals.

The time course of the present results obtained from histological analysis of the control group fits with the overall picture regarded as normal dermal healing (Albuquerque-Júnior et al.). However, the use of both wound dressings improved the development of the granulation tissue and, collagen deposition, attesting the significance of wound protection for the healing process (Ojiegbe et al.; Nunes et al.).

Despite improvement of wound healing having been observed in the group treated collagen-based dressings, as already reported by Albuquerque-Júnior et al., the histological changes evidenced in the group treated with films based on mucous secretion of Achatina fulica were more distinguishable. Similarly, the improvement of wound healing resulting from the application of mucous secretion of A. fulica has been previously reported (Martins et al.; Sirio et al.), attesting the healing potential of this biological material derived from giant snails.

In this study, the more rapid granulation tissue formation and maturation, as well as the earlier replacement of neutrophils (acute infiltrate) by macrophages and lymphocytes (chronic infiltrate) suggest that the chemical compounds present in those films may play an important role in modulating the angiogenesis and chronification of the inflammatory response, two important events involved in wound healing. However, the mechanisms underlying such biological properties remain unclear. It has been recently demonstrated that mucous secretion of A. fulica composed of a rich polysaccharide complex and sialic acid, elements which represent important constituents of the connective tissue (Lorenzi \& Martins, 2008). Besides, an important role played by polysaccharides on the modulation of the inflammatory response had been previously described, attesting the capability of these molecules in preventing intraperitoneal adhesion and abscess formation in a rat peritonitis model (Bae \& Barreto, 2004). On the other hand, since no significant difference in the inflammatory intensity was observed in this study, it is suggested that the modulatory activity on the leukocyte infiltrate and blood vessels formation is likely an indirect effect of other biological properties of the films. It is well-established that the release of biological compounds responsible for the chemotaxis of polymorphonuclear leukocytes is influenced by the bacterial content in the infected site (Welch et al., 1981). Thus, it is possible to speculate that the early chronicity of the inflammatory response may be a result of the antimicrobial activity of the mucus, as observed in this study and in other reports (Kubota; Gopinath et al., 2004). In addition, the release of angiogenesis-associated growth factors, such VEGF (vascular-endothelial growth factor) and PDGF (platelet-derived growth factor), after inflammatory chronification is a key-step to the development of the granulation tissue during wound healing (Dielgeman \& Evans), which could support our findings regarding to the enhanced vascularization. However, other detailed investigations assessing the effects of A. fulica's mucous secretion on the inflammatory dynamics and endothelial cells proliferation are necessary to validate this theory.

Collagens are proteins synthesized and degraded by fibroblasts which play a fundamental role in the scar tissue formation. Fibril-forming collagens in soft tissues are represented mainly by type I and III molecules (Junqueira et al., 1983). Type III collagen it is first produced in early stages of wound healing, supposedly to provide a network of adhesive macromolecules capable of orienting the migration of endothelial cells to form the granulation tissue; thereafter, this molecule is gradually replaced by type I collagen, the major molecule responsible for providing tensile strength to the tissue, so that the scar acquires mechanical stability (Albuquerque-Júnior et al.; Nunes et $a l$. .). In this study, the use of films based on mucous secretion 

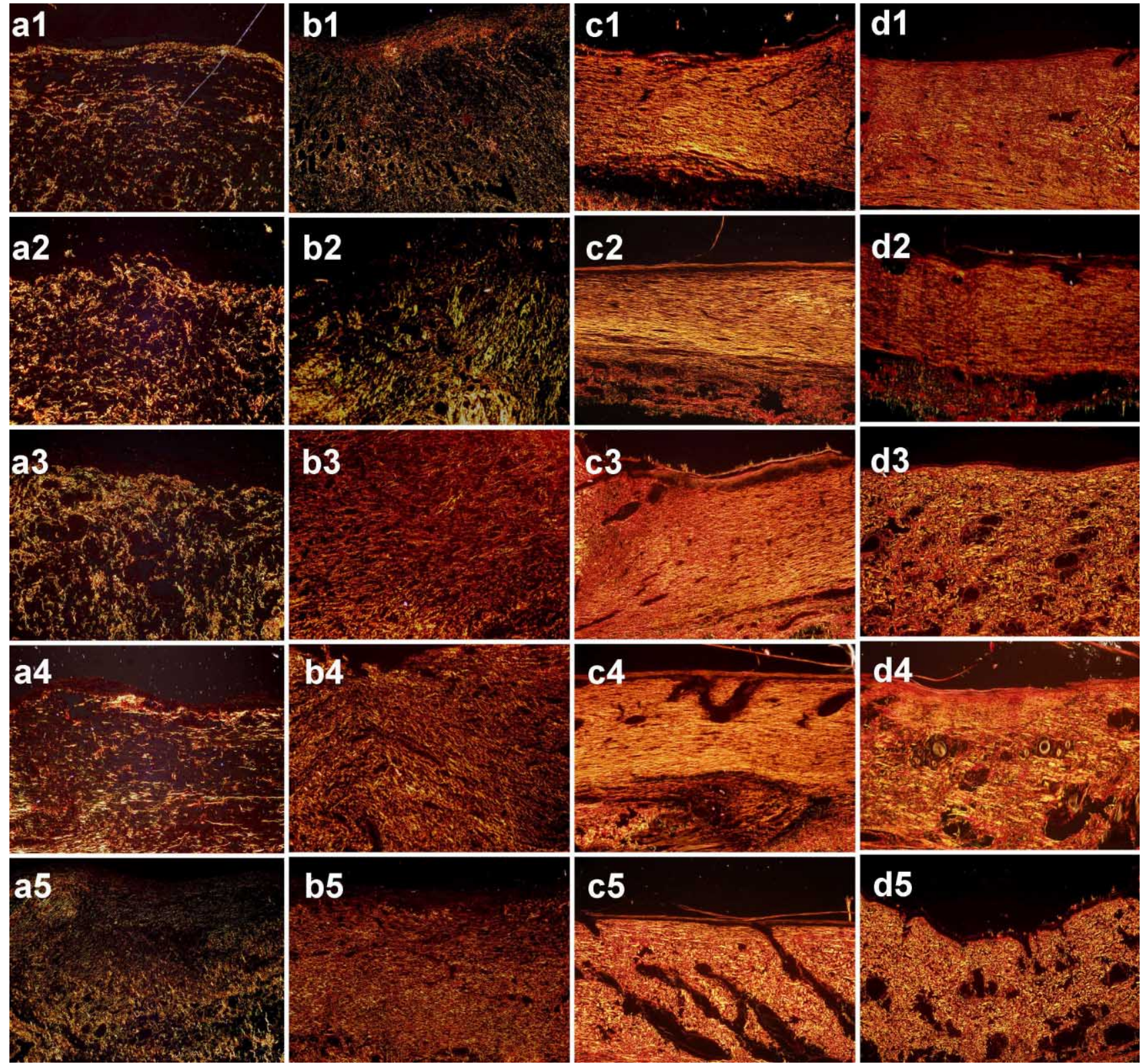

Figure 2. Histological sections observed under polarized light of the groups in 3 (a), 7 (b), 14 (c) and 21 (d) days. Type III collagen is seen as greenish and yellow-greenish fibers, whereas type I collagen is represented by orangish and reddish fibers. Vertically, the experimental groups CTR (1), COL (2), ACF (3). ACF showed earlier replacement of type III for type I collagen in 7 days (b3), denser compactation of parallel-arranged collagen fibers in 14 days (c3), interlaced disposition of the fibers in 21 days (d3) resembling the normal dermis (sirius red/polarization, 100x).

of A. fulica favored a rapid replacement of type III for type I collagen and accelerated the spatial organization of the collagen fibers from parallel disposition to interlaced arrangement, characteristic of normal dermis. Besides, the collagen content was significantly improved by such films during all the time course of the experiment. Despite the precise mechanism responsible for such improvement in the collagenization is still unknown, it is possibly related to the biochemical composition of the mucous secretion, which is rich in mucin (Lorenzi \& Martins, 2006; Sirio et al.). Mucin is characterized by numerous tandem repeats that contain proline and are rich in serine asparagine, hydroxylysine and/ or threonine residues (Adikwu, 2006). Therefore, as long as these aminoacids are closely involved in the biochemical synthesis of collagen molecules, the presence of high contents of mucin in the mucous secretion of A. fulica (data not shown) might be related to the better collagenization observed in this study. Supporting these findings, it has been 
reported that the application of snail mucin dispersed in detarium gum gel proved to be useful to improve wound healing (Adikwu \& Alozie, 2007). Notwithstanding, further investigations are required in order to unravel the precise role played by the mucous secretion's chemical compounds on the collagenization during wound healing.

In conclusion, we have demonstrated that the mucous secretion of Achatina fulica presents antibacterial properties against Staphylococcus aureus and Staphylococcus epidermidis. In addition, the use of dres- sing films based on this mucous secretion improved wound healing in rodent model.

\section{ACKNOWLEDGEMENTS}

We would like to thank The National Council of Research $(\mathrm{CNPq})$ and The Foundation to support research and technology innovation in the state of Sergipe (FAPITEC) for the financial support.

SANTANA, W.A.; MELO, C. M.; CARDOSO, J. C.; PEREIRA-FILHO, R. N.; RABELO, A. S.; REIS, F. P. \& ALBUQUERQUEJÚNIOR, R. L. C. Evaluación de la actividad antimicrobiana y la cicatrización potencial de la secreción mucosa de Achatina fulica. Int. J. Morphol., 30(2):365-373, 2012.

RESUMEN: A la secreción mucoproteica del Achatina fulica se le han asignado propiedades antibacterianas, antifúngicas y cicatriciales que pueden estar influidas por el tipo de alimento que se ofrece a este especimen. Este estudio investigó el potencial curativo de películas basadas en la secreción mucosa de Achatina fulica alimentaba con diferentes tipos de plantas. Fueron tratadas heridas provocadas en el dorso de ratas Wistar con películas de colágeno y películas realizadas a partir de la secreción mucosa de A. fulica, alimentados con plantas de lechuga (L. sativa), utilizando como parámetro de comparación la curación del grupo de control. Después de 3,7,14 y 21 días los animales fueron sacrificados y las heridas fueron evaluadas microscópicamente. En los días 3 y 7, las heridas tratadas con moco mostraron mejores tasas de formación y maduración del tejido de granulación, epitelización, y más rápido recambio de colágeno tipos III y I. A los días 14 y 21, hubo una intensa deposición del colágeno tipo I y aceleración en la regeneración de la piel. Los resultados obtenidos a partir de A. fulica alimentados con plantas de lechuga (L. sativa) mostraron mejores resultados. Este estudio sugiere que las películas producidas con secreción mucosa de $A$. fulica pueden ser utilizadas con éxito como apósito, especialmente si los caracoles se alimentan con plantas de lechuga L. sativa.

PALABRAS CLAVE: Cicatrización de heridas; Vendajes; Caracol de tierra; Moco.

\section{REFERENCES}

Adikwu, M. M. Mucins and their potentials (editorial). Trop. J. Pharm. Res., 5:581-2, 2006.

Adikwu, M. U. \& Alozie, B. U. Application of snail mucin dispersed in detarium gum gel in wound healing. Sci. Res. Essay, 2(6):195-8, 2007.

Albuquerque-Júnior, R. L. C.; Barreto, S. A. L.; Pires, A. J.; Reis, P. F.; Lima, O. S.; Ribeiro, G. M. A. \& Cardoso, C. J. Effect of bovine type-I collagen-based films containing red propolis on dermal wound healing in rodent model. Int. J. Morphol., 27(4):1105-10, 2009.

Antunes A. L.; Secchi, C.; Reiter, K. C.; Perez, L. R.; de Freitas, A. L. \& D'Azevedo, P. A. Feasible identification of Staphylococcus epidermidis using desferrioxamine and fosfomycin disks. APMIS, 116:16-20, 2008.

Bae, J. S. \& Barreto, S. A. The effect of polysaccharides and carboxylcellulose combination to prevent intraperitoneal adhesion and abscess formation in a rat peritonitis model. $J$. Vet. Med. Sci., 66(10):1205-11, 2004.
Caetano, M. D. Los animales usados en la medicina popular mexicana. Ciudad de México, Imprenta Universitária, 2000. p.126.

Chong, H. C.; Tan, M. J.; Philippe, V.; Tan, S. H.; Tan, C. K.; Ku, C. W.; Goh, Y. Y.; Wahli, W.; Michalik, L. \& Tan, N. S. Regulationof epithelial-mesenchymal IL-1 signaling by PPARbeta/delta is essential for skin homeostasis and wound healing. J. Cell Biol., 184(6):817-31, 2002.

Chowdary, V. S.; Vinaykumar, E. C.; Rao, J. J.; Ratna Rao; Ram Babu, K. \& Rangamani, V. A Study on Serum IgE and Eosinophils in Respiratory Allergy Patients. Indian J. Allergy Asthma Immunol., 17(1):21-4, 2003.

Cruse, P. J. \& Foord, R. The epidemiology of wound infection. A 10-year prospective study of 62,939 wounds. Surg. Clin. North Am., 60(1):27-40, 1980.

Diegelman, E. V. \& Evans, C. S. Official Analytical Chemists. $13^{\text {th }}$ Ed. Washington D.C., Official methods of analysis of the Association of Official Analytical Chemists, 2004. 
Ehart, W. S. \& Floyd, D. G. Evolution of snails morphology and function: an integrative approach of adaptation, constraint, and compromise. New York, Studies on Practice Animal and Plants, 2002. pp.241-71.

Fuchino, G. M. \& Barrett, S. S. H. Introduction a l'ethnomédecine. In: Bannerman, R. H. (Ed.). Médicine traditionelle et couverture des soins de santé. Genebra, Suíça, OMS, 1992. p.17-24.

Gopinath, D.; Ahmed, M. R.; Gomathi, K.; Chitra, K.; Sehgal, P. K. \& Jayakumar, R. Dermal wound healing processes with curcumin incorporated collagen films. Biomaterials, 25(10):1911-7, 2004.

Iguchi, S. M. M.; Aikawa, T. \& Matsumoto, J. J. Atividade antibacteriana do muco mucina de caracóis. Comp. Biochem. Physiol., 27(3):571-4, 1982.

Junqueira, L. C.; Montes, G. S.; Martins, J. E. \& Joazeiro, P. P. Dermal collagen distribution. A histochemical and ultrastructural study. Histochemistry, 79(3):397-403, 1983.

Kubota, Y. Purificação e caracterização do fator antibacteriano do muco de escargots. Comp. Biochem. Physiol., 82(2):345-8, 1985.

Lorenzi A. T. \& Martins, M. F. Análise colorimétrica e espectroscópica do muco de caracóis terrestres Achatina sp alimentados com ração diferenciada. R. Bras. Zootec., 37(3):572-9, 2006.

Lorenzi, A. T. \& Martins, M. F. Análise colorimétrica e espectroscópica do muco de caracóis terrestres Achatina sp alimentados com ração diferenciada. R. Bras. Zootec., 37(3):572-9, 2008.

Maluf-Meiken, L. C.; Silva, D. R.; Duek, E. A. \& Alberto-Rincon, M. C. Morphometrical analysis of multinucleated giant cells in subdermal implants of poly-lactic acid in rats. J. Mater. Sci. Mater. Med., 17(5):481-5, 2006.

Martin, P. Wound healing--aiming for perfect skin regeneration. Science, 276(5309):75-81, 1997.

Martins, M. F.; Caetano, F. A. M. \& Sírio, O. J. Avaliação do reparo de lesões de pele de coelhos tratadas com secreção mucoglicoproteica do escargot Achatina. Braz. J. Vet. Res. Anim. Sci., 1(1):1-11, 2003.

Moylan, J. A. \& Kennedy, B. V. The importance of gown and drape barriers in the prevention of wound infection. Surg. Gynecol. Obstet., 151(4):465-70, 1980.

Nunes, P. S.; Albuquerque, R. L. Jr.; Cavalcante, D. R.; Dantas, M. D.; Cardoso, J. C.; Bezerra, M. S.; Souza, J. C.; Serafini, M. R.; Quitans, L. J. Jr.; Bonjardim L. R. \& Araújo, A. A. CollagenBased Films Containing Liposome-Loaded Usnic Acid as Dres- sing for Dermal Burn Healing. J. Biomed. Biotechnol., 2011:761593, 2011.

Ojiegbe, G. C.; Njoku-Obi, A. N. \& Ojukwu, J. O. Incidence and parametric determinants of post-operative wound infections in a university teaching hospital. Cent. Afr. J. Med., 36(3):637, 1990.

Onche, I. \& Adedeji, O. Microbiology of Post-operative Wound Infection in Implant Surgery. Nig. J. Surg. Res., 6(1-2):37-40, 2004.

Rich, L. \& Whittaker, P. Collagen and picrosirius red staining: a polarized light assessment of fibrillar hue and spatial distribution. Braz. J. Morphol. Sci., 22(2):97-104, 2005.

Shakespeare, P. Burn wound healing and skin substitutes. Burns, 27(5):517-22, 2001.

Shriyan, A.; Sheetal, R. \& Nayak, N. Aerobic Micro-organisms in Post-operative Wound Infections and their Antimicrobial Susceptibility Patterns. J. Clin. Diag. Res., 10(4):3392-6, 1995.

Singer, A. J. \& Clark. R. A. Cutaneous wound healing. New Eng. J. Med., 341(10):738-46, 1999.

Sírio, O. J. Verificação da potencialização do efeito cicatrizante do muco de caracóis do gênero Achatina promovida por dieta a base de Confrei (Symphytum officinale L.). Dissertação, Mestrado. Programa de Pós-Graduação em Nutrição e Produção Animal. Faculdade de Medicina Veterinária. Pirassununga, Universidade de São Paulo, 2005. p.87.

Welch, W. D.; Davis, D. \& Thrupp, L. D. Effect of antimicrobial agents on human polymorphonuclear leukocyte microbicidal function. Antimicrob. Agents Chemother., 20(1):15-20, 1981.

Werner, S. \& Grose, R. Regulation of wound healing by growth factors and cytokines. Physiol. Rev., 83(3):835-70, 2003.

Yomassa, S. E. F. Medicamentos a partir de plantas medicinais no Brasil. Rio de Janeiro, Academia Brasileira de Ciências, 2002.

Correspondence to:

Cláudia Moura de Melo

Av. Murilo Dantas, 300, Prédio do ITP

Farolândia, Aracaju/SE

CEP 49032-490

BRASIL

Email: wagnoalcantara@hotmail.com

Received: 20-06-2011

Accepted: 10-01-2012 